\title{
Evaluation of Synergistic Effect of Neem and Poultry Manure on Root Knot Nematode (Meloidogyne spp.) Infecting Rice
}

\author{
Hassan Mohammed Auwal*, Ibrahim Buba Galadima, Jacob Madu, Paul Joseph \\ Department of Crop Protection, Faculty of Agriculture, University of Maiduguri, Maiduguri, Nigeria \\ Email: ${ }^{*}$ hassanma2K@gmail.com
}

Received 15 February 2015; accepted 1 March 2015; published 4 March 2015

Copyright (C) 2015 by authors and OALib.

This work is licensed under the Creative Commons Attribution International License (CC BY). http://creativecommons.org/licenses/by/4.0/

(c) (i) Open Access

\section{Abstract}

Field experiment was conducted in 2014 to test the efficacy of different organic amendments on the control of root-knot nematode (Meloidogyne spp.). The different materials are sole neem, sole poultry manure, and a combination of neem and poultry manure. Neem was applied at the rate of $160 \mathrm{~g}$ per plot, poultry manure was applied at the rate of $1120 \mathrm{~g}$ per plot, combination of neem and poultry manure was applied at $1280 \mathrm{~g}$ per plot and Furadan was applied at $16 \mathrm{~g}$ per plot. Nonamended plot served control. Results obtained showed a combination of neem and poultry manure that produced the highest nematode suppression with a population of 58.3 , followed by sole neem and poultry manure that produced $81.7,94.7$ respectively. This is compared to the chemical nematicide, Furadan that produced the least population of 41.7. The control treatment produced the highest population of 226.7. Reduction in nematodes population was concomitant to increase in rice growth and yield parameters. Combination of neem and manure produced the highest rice yield of $108 \mathrm{~g}$ which is significantly not different from manure that produced $107 \mathrm{~g}$ of rice. Among the three experimental factors neem produced the least rice yield of $88.2 \mathrm{~g}$. This is compared to Furadan that produces $140.7 \mathrm{~g}$ rice. The non-amended control treatment produced the smallest quantity of rice which is $66.5 \mathrm{~g}$.

\section{Keywords}

Synergy, Neem and Poultry Manure, Meloidogyne spp., Rice

Subject Areas: Plant Science

${ }^{*}$ Corresponding author.

How to cite this paper: Auwal, H.M., Galadima, I.B., Madu, J. and Joseph, P. (2015) Evaluation of Synergistic Effect of Neem and Poultry Manure on Root Knot Nematode (Meloidogyne spp.) Infecting Rice. Open Access Library Journal, 2: e1372. http://dx.doi.org/10.4236/oalib.1101372 


\section{Introduction}

Rice (Oryza sativa L) is the most widely grown cereal crop worldwide and over 738.2 million metric tons of rice is produced in 2012 [1]. It constitutes the staple food for 2.5 billion people [2], and rice cultivation has the largest land use for producing food, covering 9\% of the earth's arable land. In Africa rice is serve as an important food crop with a yield of about $5082 \mathrm{~kg} / \mathrm{ha}$ [1]. However, plant parasitic nematodes cause global yield losses estimated at $10 \%$ to rice production annually [3]. Nevertheless, most African farmers are usually unaware of nematodes existence, and they have become important limiting factor to the production of agricultural crops in Nigeria. Consequently, the damage they cause globally is neglected by both farmers and agricultural researchers [4]. At present, the most widely used method for control of nematodes is the use of synthetic chemical nematicides, which, although highly effective, more convenient in use and drastic in their action against the pest and diseases, they are now being re-appraised globally due to their undesirable effect on the environment, man and biodiversity. However, botanicals offer great potentials as environment friendly alternatives to synthetic chemicals. Therefore, the main aim of this study is to search for sustainable and environment friendly alternative method of control root knot nematodes on rice. The specific objectives are as follows: 1) To assess the nematicidal efficacy of sole neem and poultry manure and combination of the two materials applied to soil as organic amendments, and 2) to evaluate possibility of synergistic effect of the mixture of the two materials in control of nematodes.

\section{Materials and Methods}

The experiment is conducted in the Faculty of Agriculture, University of Maiduguri research farm. The experiment site is located at the latitude $40^{\circ} \mathrm{N}$.E and longitude $48^{\circ} \mathrm{N}$.S. The semi-arid region where the research site is located is characterized by their short rainy season of about 3 - 4 months with an annual rainfall from $300 \mathrm{~mm}$ $350 \mathrm{~mm}$ and the soil is a composition of sandy-loamy [5].

Neem (Azadirachtaindica), poultry manure, nematicide (Furadan) and rice seedlings were used as materials for the experiment. Neem (Azadirachtaindica), seed was collected from the University of Maiduguri around the experimental site. It was dried and grounded into a powder form and dry poultry manure was brought from the University of Maiduguri poultry farm. The plant material was weighed at 10 grams for each plant stand and 70 grams weighed for the dry poultry manure each stand of plant. Nematicide (Furadan) was bought from accredited dealers at Monday market of Maiduguri Metropolitan City (MMC) and was measured 1gram applied per crop stand.

The experiment was carried out in randomize complete block design (RCBD) design with three replications and five treatments within each replication. The treatments are namely; powdered neem kernel $(\mathrm{N})$, poultry manure $(\mathrm{M})$ and a combination of neem and poultry manure $(\mathrm{N}+\mathrm{M})$. Furadan was used as a standard for comparison with the experimental factors. Non-amended plots served control. The plots were measured $2 \mathrm{~m} \times 2 \mathrm{~m}$ and spacing of $1 \mathrm{~m}$ between plot and replication.

Data were collected on two sets of parameters. The nematodes population parameters and plant growth and yield parameters. The nematodes population parameters include the initial and final nematodes population. The plant growth and yield parameters consist of the shoot height, root length, dry shoot and root weight. Data were collected on the number of nematode population available in the soil. Soil samples numbering 5 per plot and measuring $200 \mathrm{~cm}^{3}$ were collected before transplanting for analysis of the initial nematodes population (Pi) and also on crop harvest for analysis of the final nematodes population (Pf). All soil samples were collected in polythene bags, labeled with plot number and dates. The soil samples were all subjected to extraction of the nematodes, counting, and identification.

Rice was harvested after 70 days of transplanting. The crops were carefully uprooted from the soil and roots were washed to remove any adhering soil particles and taken to the laboratory in polythene bags. The roots were cut off from the stem and carefully examined and scored for number of galls per 10 gram root. The rice panicles containing the seeds were carefully severed from the rest of the stem. The seeds were measured per plot. The shoot height was measured using a meter rule from the point of attachment to root to the panicle. Root length is measured using the meter rule. The sample plants were exposed to sun light under a shed for 4 days in other to extract the moisture content. Dry shoot and root weight was measured in grams using an electric digital weighing machine.

Data was analyzed using the analysis of variance (ANOVA) method. Means were separated by means of Fishers least significant difference (LSD) at 0.05 level of significance. 


\section{Result and Discussion}

Table 1 showed the effect of sole neem kernel powder, sole poultry manure, and combination of neem with poultry manure on root-knot nematode population infecting rice. There is no significant $(\mathrm{P}<0.05)$ difference in the initial population $(\mathrm{Pi})$. Sole poultry manure showed significant $(\mathrm{P}<0.05)$ difference with the highest final nematode population (Pf) of 94.67, followed by sole neem with 81.67 and the combination of neem and poultry with 58.33. This is compared to Furadan which produced the least nematodes population of 41.67. The untreated (control) produced the highest final nematode population (Pf) of 226.67. The reproductive factor (RF) which depicts the relationship between the Pf and Pi showed that nematicide exhibited the least significant $(\mathrm{P}<0.05)$ nematodes population with 0.42 followed by the combination of neem with poultry manure (synergy) with 0.54 in an increasing order, while poultry manure and neem gave 0.98 and 1.63 respectively and the untreated (control) with 2.19 showed the highest in the reproductive factor parameter.

This result is in accordance which the studies conducted by [6] where it was observed that the nematicidal activities of poultry manure, alone or in combination with neem (Azadirachta indica) extracts were tested against Meloidogyne javanica. Soil application of these amendments or the neem extracts alone did not reduce the root galling index of tomato plants or did so only slightly, but application of the amendments in combination withthe neem extracts reduced root galling significantly.

Several medicinal and herbal plants, such as Mentha spicata, Artemisia annua, neem (Azadirachta indica) and karanja (Pongamia glabra), have been tested for their nitrification-inhibiting efficacy [7]. In particular, karanjaand neem extracts have been found to be relatively effective in inhibiting nitrification [8]. Several parts of neem trees and their extracts are known to exhibit insecticidal, fungicidal and nematicidal activities [9] [10] and many neem-based pesticidal formulations have been developed and marketed.

Table 2 showed the effect of sole neem, sole poultry manure and combination of neem with poultry manure on the growth and yield of rice infested with root-knot nematode. All treatments resulted in significant increase in the plant growth parameters compare to the untreated (control). Sole poultry manure produced a shoot height measuring $27.03 \mathrm{~cm}$ and which significantly $(\mathrm{P}<0.05)$ the same as that produced by combination of neem with poultry manure with $26.20 \mathrm{~cm}$. Neem produced a shoot height of $17.90 \mathrm{~cm}$. These are compared to Furadan with

Table 1. Effect of sole neem kernel powder, sole poultry manure, and combination of neem with poultry manure on rootknot nematode population infecting rice.

\begin{tabular}{cccc}
\hline Treatments & Rates of Initial Appl Population (g) (Pi) & Final Population (Pf) & Reproductive Factor (Rf) \\
\hline Neem (N) & $160100.00 \mathrm{a}$ & $81.67 \mathrm{~b}$ & $1.63 \mathrm{ab}$ \\
Manure (M) & $112097.00 \mathrm{a}$ & $94.67 \mathrm{~b}$ & $0.98 \mathrm{ab}$ \\
N + M & $1280108.67 \mathrm{a}$ & $58.33 \mathrm{~b}$ & $0.54 \mathrm{~b}$ \\
Furadan & $16 \mathrm{~g} 106.67 \mathrm{a}$ & $41.67 \mathrm{~b}$ & $0.42 \mathrm{~b}$ \\
Control & $0.0 \mathrm{~g} 104.33 \mathrm{a}$ & $226.67 \mathrm{a}$ & $2.19 \mathrm{a}$ \\
\hline
\end{tabular}

Means are average of three replications. Means followed by the same latter within each column are not significantly different $(\mathrm{P}<0.05)$ as indicated by Fisher's least significant difference (L.S.D) test.

Table 2. Effect of sole neem, sole poultry manure and combination of neem with poultry manureon the growth and yield of rice infested with root-knot nematode.

\begin{tabular}{cccccc}
\hline Treatments & Shoot height $(\mathrm{cm})$ & Root length $(\mathrm{cm})$ & Dryshoot weight $(\mathrm{g})$ & Dry root Weight $(\mathrm{g})$ & Rice Yield (g) \\
\hline Neem $(\mathrm{N})$ & $17.90 \mathrm{bc}$ & $5.70 \mathrm{bc}$ & $5.70 \mathrm{a}$ & $9.13 \mathrm{ab}$ & $88.17 \mathrm{bc}$ \\
Manure $(\mathrm{M})$ & $27.03 \mathrm{ab}$ & $5.27 \mathrm{~cd}$ & $5.27 \mathrm{a}$ & $10.07 \mathrm{ab}$ & $106.98 \mathrm{~b}$ \\
$\mathrm{~N}+\mathrm{M}$ & $26.20 \mathrm{ab}$ & $8.02 \mathrm{a}$ & $6.37 \mathrm{a}$ & $12.53 \mathrm{a}$ & $108.35 \mathrm{~b}$ \\
Furadan & $33.40 \mathrm{a}$ & $7.56 \mathrm{ab}$ & $7.74 \mathrm{a}$ & $10.88 \mathrm{a}$ & $140.67 \mathrm{a}$ \\
Control & $12.03 \mathrm{c}$ & $3.10 \mathrm{~d}$ & $2.20 \mathrm{~b}$ & $4.06 \mathrm{~b}$ & $66.54 \mathrm{c}$
\end{tabular}

Means are average of three replications. Means which are followed by the same latter within each column are not significantly different (P<0.05) as indicated by Fisher's least significant difference (L.S.D) test. 
produced a shoot height of $33.40 \mathrm{~cm}$, which is significantly $(\mathrm{P}<0.05)$ the highest shoot height produced. Similar trend is observed in root length. Combination of neem with poultry, sole neem and sole poultry manure produced $6.37 \mathrm{~g}, 5.70 \mathrm{~g}$, and $5.27 \mathrm{~g}$ respectively. These are compared toFuradan that produced a dry shoot weight of $7.74 \mathrm{~g}$. Untreated (control) produce $2.20 \mathrm{~g}$ which is significant $(\mathrm{P}<0.05)$ the least in dry shoot weight.

Combination of neem with poultry manure produces significantly $(\mathrm{P}<0.05)$ dry root weight of the highest of $12.53 \mathrm{~g}$. This is followed by sole poultry manure and sole neem which produced $10.07 \mathrm{~g}$ and $9.13 \mathrm{~g}$ respectively. This is compared to Furadan that produced $10.88 \mathrm{~g}$. The untreated (control) plots produced $4.06 \mathrm{~g}$, which is significantly $(\mathrm{P}<0.05)$ the least of the dry root weight. The combination of neem with poultry manure and sole poultry manure produced $108.35 \mathrm{~g}, 106.98 \mathrm{~g}$ respectively which are significantly $(\mathrm{P}<0.05)$ not different. These are followed by neem that produced $88.17 \mathrm{~g}$ which is significantly $(\mathrm{P}<0.05)$ different from the preceding two treatments. These are compared to Furadan that produced 140.67 g significantly $(\mathrm{P}<0.05)$ the highest of the yield. The untreated (control) produced $66.54 \mathrm{~g}$ which is significantly the least in yield.

\section{Conclusion}

Combination of neem and poultry has been showed to suppress root knot nematode population in the soil considerably, and allowed better plant establishment. It is evident from this work that the use of neem with poultry manure is very effective in suppressing plant parasitic nematode, especially root-knot nematodes and enhanced maximum crop production. It is therefore concluded from this research point of view that farmers should adopt and practice the application of organic materials into the soil on their farms where nematodes are seen to destroy crop productivity since these methods have been shown to be less stressful and economical towards controlling root knot nematodes and enhance maximum crop production. Moreover, the use of these natural resource products can serve as organic alternative to synthetic nematicides in a sustainable farming system.

\section{References}

[1] FAO (2012) Food and Agricultural Organization, Production Figure. http://faostat.fao.org/site/339/default.aspx

[2] Ito, S. and Ishikawa, Y. (2004) Marketing of Value-Added Rice Products in Japan: Germinated Grown Rice and Rice Bread. Proceedings of the FAO International Rice Year, 2004 Symposium, Tottori University, Rome, 1-9.

[3] Sasser, J.N. and Freckman, D.W. (1987) A World Perspective on Nematology: The Role of the Society. In: Veech, J.A. and Dickson, D.W., Eds., Vistas on Nematology, Hyattsville, Maryland, 7-20.

[4] Coyne, D.L. and Polywright, R.A. (2004) Nematode Parasites of Rice WARDA and IRRI. In: Dropkin, V.H., Ed., Introduction to Plant Nematology, John Wiley \& Sons Inc., Hoboken.

[5] Grema, A.K (1994) Production of Pearl Millet and Cowpea Inter Crop in North Eastern Nigeria. Ph.D. Thesis Unpublished Work, Infestation by a Root-Knot Nematode, Meloidogyne Incognita, Chitwood.

[6] Oka, Y. and Pivonia, S. (2002) Use of Ammonia-Releasing Compounds for Control of the Root-Knot Nematode Meloidogyne javanica. Journal of Nematology, 4, 65-71. http://dx.doi.org/10.1163/156854102760082212

[7] Usha, K. and Patra, D.D. (2003) Medicinal and Aromatic Plantmaterials as Nitrification Inhibitors for Augmenting Yield and Nitrogen Uptake of Japanese Mint (Mentha arvensis L. Var. Piperascens). Bioresource Technology, 86, 267-276. http://dx.doi.org/10.1016/S0960-8524(02)00143-8

[8] Gnanavelrajah, N. and Kumaragamae, D. (1998) Effect of Neem (Azadirachta indica A. Juss) Materials on Nitrification of Applied Urea in Three Selected Soils of Sri Lanka. Tropical Agricultural Research, 10, 61-73.

[9] Raguraman, S., Ganapathy, N. and Venkatesan, T. (2004) Neem versus Entomopathogens and Natural Enemies of Crop Pests: The Potential Impact and Strategies. In: Koul, O. and Wahab, S., Eds., Neem: Today and in the New Millennium, Kluwer Academic Publishers, Dordrecht, 125-182. http://dx.doi.org/10.1007/1-4020-2596-3 8

[10] Suresh, G., Gopalakrishnan, G. and Masilamani, S. (2004) Neem for Plant Pathogenic Fungal Control: The Outlook in the New Millennium. In: Koul, O. and Wahab, S., Eds., Neem: Today and in the New Millennium, Kluwer Academic Publishers, Dordrecht, 183-208. http://dx.doi.org/10.1007/1-4020-2596-3_9 